important factor in the response to shunting. The mechanism of this carbohydrate intolerance may well be similar to that in our patients, whose endocrinological damage may have been primarily hypothalamic. The clinical importance of any pituitary insufficiency depends on its extent and permanence. In case 1 the defect appeared to be static and required long-term replacement treatment. Failure to provide such hormonal treatment might have rendered the dementia permanent simply by substituting a metabolic cause for a mechanical one. Weakness from the adrenocortical and androgen deficiencies may prevent an appreciable improvement in gait.

Thus five of our patients with normal-pressure hydrocephalus showed endocrine disturbance, which may affect immediate operative survival and the long-term response to treatment. We believe, therefore, that all such patients should be assessed endocrinologically before surgical intervention and, when necessary, replacement treatment started.
We wish to thank Professor W Butt, department of clinical endocrinology, Women's Hospital, Birmingham, for help with the assays, and Hoechst Pharmaceuticals Ltd, who supplied the gonadotrophinreleasing hormone.

\section{References}

1 Simonds, J P, and Brandes, W W, Archives of Pathology, 1926, 2, 18.

${ }^{2}$ Kovacs, K, Neuroendocrinology, 1969, 4, 170.

${ }^{3}$ Barber, S G, and Garvan, N, British Medical fournal, 1978, 1, 817.

4 Kandeel, F R, et al, Clinical Endocrinology, 1978, 9, 429.

${ }^{5}$ Nakajima, $T$, et al, Proceedings of Annual Meeting of the Fapanese Endocrinological Society, 1971, p 2.

${ }^{6}$ Lancet, 1977, 2, 1011.

7 Jacobs, L, Fournal of Neurology, Neurosurgery and Psychiatry, 1977, 40, 331

${ }^{8}$ Shaw, R W, MD thesis, Birmingham University, 1975.

(Accepted 1 March 1979)

\title{
Asthma in the elderly: an epidemiological survey
}

\author{
M L BURR，T J CHARLES，K ROY，A SEATON
}

British Medical fournal, 1979, 1, 1041-1044

\section{Summary and conclusions}

A random sample of one in eight people aged 70 and over living at home in a south Wales town was surveyed to establish the prevalence of asthma. Subjects attended a screening clinic, where spirometry before and after an inhalation of salbutamol, skin prick testing, blood count, and sputum examination were carried out and a questionnaire answered. Those in whom asthma seemed at all likely were subsequently examined in detail in a chest clinic. Out of 485 subjects eligible, $418(86 \cdot 2 \%)$ were screened. Twelve $(2.9 \%)$ had current asthma, of whom three had not previously been diagnosed as asthmatic and four were being treated but were unaware of the diagnosis. A further $15(3.6 \%)$ had mild asthma or a history of the disease, giving a total prevalence of any history of asthma of $6.5 \%$. Only one of the subjects who did not attend the screening clinic was known to have asthma, suggesting that the overall prevalence did not differ greatly from this figure. It was found that the disease might start or remit at any age.

Thus in the elderly current asthma is more prevalent in men than women (5.1\% compared to $1.8 \%)$ and in terms of spirometry is more severe. Two underlying disease processes may perhaps exist that fulfil criteria for asthma in the elderly, one causing sputum eosinophilia and the other a form of chronic bronchitis with reversible airways obstruction.

\section{MRC Epidemiology Unit, Cardiff CF2 3AS}

M L BURR, MD, MFCM, epidemiologist

Llandough Hospital, Penarth, South Glamorgan

T J CHARLES, MB, MRCP, senior registrar (present appointment : consultant physician, Abergele Hospital, Abergele, North Wales)

K ROY, FIMLT, senior laboratory scientist

A SEATON, MD, FRCP, consultant physician (present appointment: director, Institute of Occupational Medicine, Edinburgh EH8 9SU)

\section{Introduction}

Asthma is difficult to diagnose in the elderly because it is often "intrinsic"-that is, it lacks those allergic characteristics that help to distinguish it in younger people-and because chronic bronchitis, which may cause similar symptoms, is common in old people. When partially reversible airways obstruction is present it is particularly difficult to distinguish between the two diseases. Because we had gained the clinical impression that asthma is common in the elderly and often undiagnosed we carried out a survey to discover the prevalence of asthma and reversible airways obstruction among old people living at home.

\section{Subjects and methods}

The survey took place in a south Wales town. We drew a random sample of one in eight of all people aged 70 years and over who were registered with the local general practitioners. Residents of old people's homes and long-stay hospital wards were excluded. The subjects were invited to attend a screening clinic or were visited at home. Those who reported a productive cough were given sputum pots containing $70^{\circ}$ alcohol and asked to provide a specimen of sputum, which was examined for asthmatic stigmata. ${ }^{1}$ At the clinic a short, detailed questionnaire was completed asking about respiratory symptoms. Wheezing was defined in terms of whistling, ${ }^{2}$ and questions were asked about recent attacks ("Have you had an attack of shortness of breath with wheezing at any time in the last 12 months ?"), nocturnal dyspnoea ("Has your sleep been disturbed by breathlessness or wheezing at any time in the last 12 months ?"), and asthma ("Have you at any time in your life-even in childhood-had asthma?"). Lungfunction tests, measuring forced expiratory volume in one second $\left(\mathrm{FEV}_{1}\right)$ and forced vital capacity (FVC), were performed before and 15 minutes after inhalation of two puffs of salbutamol, using a vitalograph. Skin prick tests to house dust, mite extract (Dermatophagoides pteronyssinus), grass pollens, Aspergillus fumigatus, and cat fur were performed. Blood was taken for eosinophil counts and the subjects weighed and measured.

Subjects whose history and lung function suggested asthma were referred to a hospital chest clinic. These subjects comprised all those who claimed to have current asthma, who reported noctural dyspnoea, and who complained of wheezing and breathlessness during the previous 12 months and whose $\mathrm{FEV}_{1}$ improved by $15 \%$ or more after an inhalation of salbutamol. At the chest clinic chest radiography was performed and the subjects were given a full clinical examination by a 
physician (TJC), including spirometry and more detailed lung-function tests when indicated. The names of subjects who refused to attend the initial screening clinic were submitted to their general practitioners, who were asked whether any of them had asthma.

\section{Results}

Out of 153 men and 332 women who were eligible to attend the screening clinic, 138 men and 280 women did so. Response rates were thus $90 \cdot 2 \%$ and $84.3 \%$ respectively $(86.2 \%$ overall). Forty subjects were eligible for referral to the hospital chest clinic, of whom five were already attending the clinic, one refused further investigation, and three were visited at home by the physician. In one man carcinoma of the lung was diagnosed after malignant cells were detected in his sputum.

Patients were classified as "current asthmatics" when all the following criteria were fulfilled. (1) Wheezing and breathlessness had occurred at some time during the previous 12 months, not due to heart disease; (2) $\mathrm{FEV}_{1}$ improved by $15 \%$ or more after a salbutamol inhalation; and (3) there was a consistent response to treatment with steroids (oral or inhaled) or bronchodilators. Twelve subjects had current asthma by these criteria, and in each case the diagnosis was supported by the clinical history. Three had not been receiving any appropriate treatment, since they had not previously been diagnosed as asthmatic. Four patients were being treated but were unaware of the diagnosis. Thus the prevalence of current asthma was $5 \cdot 1 \%$ in the men, $1.8 \%$ in the women, and $2.9 \%$ overall. Of those who refused to attend the screening clinic, only one woman was known to have asthma, suggesting the the true prevalence did not differ greatly from these figures.

Some subjects who did not fulfil all the above criteria were classified as "mild asthmatics" or "ex-asthmatics." Three were considered to have mild asthma on the grounds of typical histories, and others reported past asthma with no attacks during the previous 12 months. There was no clear-cut distinction between subjects with mild asthma and ex-asthmatics, since some subjects claimed that their asthma had stopped despite occasional wheezing, and three sometimes took treatment for wheezing. Out of 24 subjects who complained of nocturnal dyspnoea, five had current asthma, two mild asthma, eight cardiac conditions (mostly left ventricular failure), six other chest conditions (mostly chronic bronchitis), two had had the symptom once with an acute chest infection, and one refused further investigation.

Table I shows the results of lung-function tests. The "other wheezers" were subjects who complained of breathlessness and wheezing during the previous 12 months but were not classified as asthmatic. Non-asthmatics who did not have breathlessness and wheezing were termed "non-wheezers." Men and women with current asthma had a reduced $\mathrm{FEV}_{1}$ and $\mathrm{FEV}_{1} \%$ as well as an appreciable rise in $\mathrm{FEV}_{1}$ after salbutamol inhalation. Of those with mild asthma and the ex-asthmatics, the women had fairly normal lung function whereas the men tended to resemble the current asthmatics, but the numbers were too small for definite conclusions to be drawn. The male "other wheezers" had some impairment of $\mathrm{FEV}_{1}$ and $\mathrm{FEV}_{1} \%$. Formal statistical tests were not applied in view of the small numbers in each group.

Table II compares all subjects with any history of asthma with the other wheezers and non-wheezers in respect of various factors. A skin test was regarded as positive for weals of $2 \mathrm{~mm}$ or more in diameter unless the control solution produced a weal. The asthmatics were more likely than the others to have a family history of allergy, personal history of hay fever, blood eosinophilia, and positive skin tests, while the prevalence of cigarette smoking was highest in the other wheezers. When the asthmatics were excluded 41 men $(29 \cdot 7 \%)$ and 39 women $(13.9 \%)$ had cough and sputum fulfilling the MRC definition and could thus be regarded as having chronic bronchitis.

The figure shows details of the 27 asthmatics, with the ages of onset and remission of their asthma. In only six had the disease started before the age of 20 , and four of them said that they had not recently had an attack. An association appeared to exist between early onset and positive skin tests irrespective of whether the disease had remitted or not.

TABLE III-Sputum findings in all subjects from whom a specimen was obtained. (Figures are numbers (\%) of subjects)

\begin{tabular}{lcccc}
\hline & \multicolumn{4}{c}{ Sputum findings } \\
\cline { 2 - 5 } & \multicolumn{2}{c}{$\begin{array}{c}\text { Focal eosinophils } \\
\text { and } \\
\text { asthmatic stigmata }\end{array}$} & $\begin{array}{l}\text { Occasional } \\
\text { eosinophils }\end{array}$ & $\begin{array}{c}\text { No } \\
\text { eosinophils }\end{array}$ \\
\hline All asthmatics $(n=20)$ & $\cdots$ & $9(45)$ & $7(15)$ & $8(40)$ \\
Other wheezers $(n=31)$ & $\cdots$ & $7(23)$ & $11(35)$ & $13(42)$ \\
Non-wheezers $(n=87)$ & $\cdots$ & $22(25)$ & $16(18)$ & $49(56)$ \\
\hline
\end{tabular}

TABLE I-Mean $( \pm S D)$ age and height and results of lung-function tests

\begin{tabular}{|c|c|c|c|c|c|c|}
\hline & $\begin{array}{c}\begin{array}{c}\text { No of } \\
\text { subjects }\end{array} \\
\end{array}$ & Age (years) & Height (mm) & FEV $_{1}(1)$ & $\frac{\mathrm{FEV}_{1}}{\mathrm{FVC}}(\%)$ & $\frac{\text { Second FEV }_{1}{ }^{*}}{\text { First FEV }}(\%)$ \\
\hline 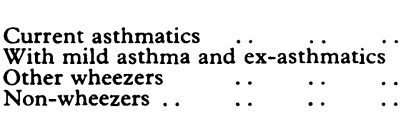 & $\begin{array}{lr}\cdots & 7 \\
\cdots & 4 \\
\cdots & 20 \\
\cdots & 107\end{array}$ & $\begin{array}{l}75 \cdot 3 \pm 4 \cdot 0 \\
74 \cdot 3 \pm 3 \cdot 9 \\
75 \cdot 4 \pm 4 \cdot 3 \\
75 \cdot 8 \pm 4 \cdot 4\end{array}$ & $\begin{array}{l}\text { Men } \\
1669 \pm 93 \\
1613 \pm 66 \\
1657 \pm 67 \\
1684 \pm 66\end{array}$ & $\begin{array}{l}0.89 \pm 0.29 \\
0.93 \pm 0.57 \\
1.36 \pm 0.68 \\
2 \cdot 08 \pm 0.64\end{array}$ & $\begin{array}{l}37 \cdot 6 \pm 5 \cdot 6 \\
41 \cdot 5 \pm 17 \cdot 6 \\
47 \cdot 9 \pm 15 \cdot 2 \\
61 \cdot 7 \pm 12 \cdot 1\end{array}$ & $\begin{array}{l}129 \cdot 4 \pm 11 \cdot 4 \\
120 \cdot 0 \pm 13 \cdot 5 \\
109 \cdot 8 \pm 9 \cdot 5 \\
105 \cdot 7 \pm 8 \cdot 1\end{array}$ \\
\hline $\begin{array}{llll}\text { Current asthmatics } & \ldots & \ldots & \ldots \\
\text { With mild asthma and } & \text { ex-asthmatics } \\
\text { Other wheezers } & \ldots & \ldots & \ldots \\
\text { Non-wheezers } \ldots & \ldots & \ldots & \ldots\end{array}$ & $\begin{array}{lr}\cdots & 5 \\
\therefore & 11 \\
\therefore & 34 \\
\therefore & 230\end{array}$ & $\begin{array}{l}76 \cdot 2 \pm 6 \cdot 3 \\
77 \cdot 0 \pm 5 \cdot 7 \\
76 \cdot 0 \pm 5 \cdot 6 \\
76 \cdot 8 \pm 5 \cdot 5\end{array}$ & $\begin{array}{l}\text { Women } \\
1524 \pm 62 \\
1517 \pm 57 \\
1543 \pm 81 \\
1539 \pm 60\end{array}$ & $\begin{array}{l}0 \cdot 86 \pm 0 \cdot 35 \\
1 \cdot 24 \pm 0 \cdot 28 \\
1 \cdot 29 \pm 0 \cdot 45 \\
1 \cdot 42 \pm 0 \cdot 42\end{array}$ & $\begin{array}{l}49 \cdot 6 \pm 7 \cdot 9 \\
60 \cdot 0 \pm 9 \cdot 7 \\
64 \cdot 7 \pm 11 \cdot 4 \\
69 \cdot 0 \pm 9 \cdot 6\end{array}$ & $\begin{array}{l}118 \cdot 6 \pm 3.9 \\
107 \cdot 7 \pm 10 \cdot 0 \\
106 \cdot 1 \pm 10 \cdot 6 \\
106 \cdot 0 \pm 6.6\end{array}$ \\
\hline
\end{tabular}

*After inhalation of salbutamol.
$\mathrm{FEV}_{1}=$ Forced expiratory volume in one second. $\mathrm{FVC}=$ Forced vital capacity.

TABLE II-Characteristics of all subjects

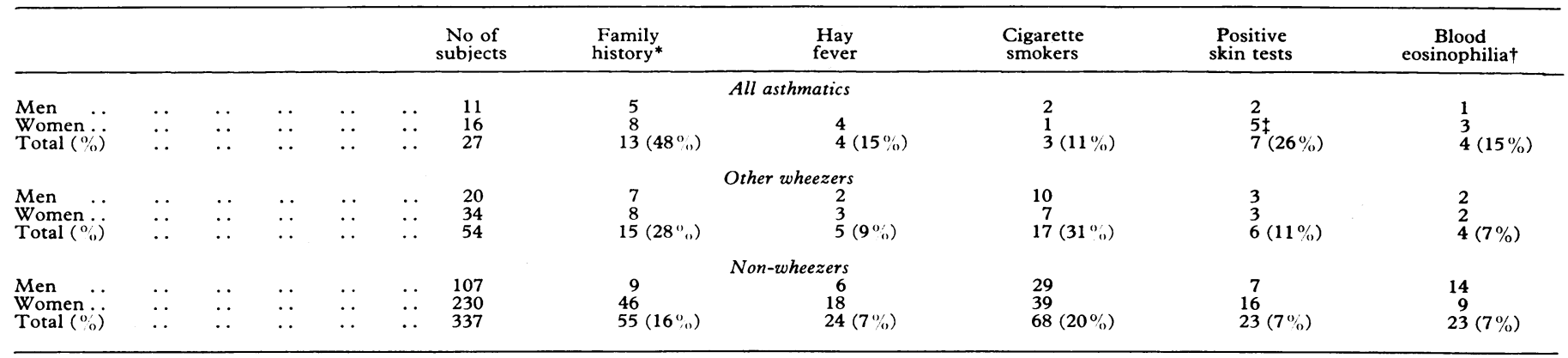

*History of asthma or hay fever in any first-degree relative.

†Over $0.4 \times 10^{9}$ eosinophils $/ 1\left(400 / \mathrm{mm}^{3}\right)$
†One woman refused skin testing. 
TABLE IV-Characteristics associated with sputum appearance. (Figures are numbers (\%) of subjects)

\begin{tabular}{|c|c|c|c|c|c|c|c|}
\hline \multirow[b]{2}{*}{ Sputum findings } & \multirow{2}{*}{$\begin{array}{l}\text { No of } \\
\text { subjects }\end{array}$} & \multicolumn{6}{|c|}{ Characteristics } \\
\hline & & $\begin{array}{c}\text { Nocturnal } \\
\text { dyspnoea }\end{array}$ & $\begin{array}{l}\text { Family } \\
\text { history }\end{array}$ & $\begin{array}{l}\text { Hay } \\
\text { fever }\end{array}$ & $\begin{array}{c}\text { Blood } \\
\text { eosinophilia* }\end{array}$ & $\begin{array}{l}\text { Positive skin } \\
\text { tests }\end{array}$ & $\begin{array}{c}\text { Salbutamol } \\
\text { effect }^{\dagger}\end{array}$ \\
\hline 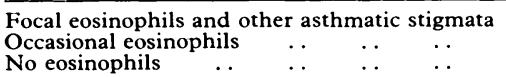 & $\begin{array}{l}38 \\
30 \\
70\end{array}$ & $\begin{array}{l}7(18) \\
4(13) \\
3(4)\end{array}$ & $\begin{array}{r}13(34) \\
5(17) \\
11(16)\end{array}$ & $\begin{array}{l}6(16) \\
2(7) \\
4(6)\end{array}$ & $\begin{array}{l}8(21) \\
3(10) \\
2(3)\end{array}$ & $\begin{array}{l}4(11) \\
4(13) \\
8(11)\end{array}$ & $\begin{array}{r}13(34) \\
9(30) \\
18(26)\end{array}$ \\
\hline
\end{tabular}

*Over $0.4 \times 10^{9}$ eosinophils $/ 1\left(400 / \mathrm{mm}^{3}\right)$. $+(\mathrm{FEV}$, after salbutamol inhalation $\times 100) /$ first $\mathrm{FEV}, \geqslant 115 \%$.

Focal eosinophils and other asthmatic stigmata were found in the sputum of about half the asthmatics from whom sputum was obtained. One current asthmatic (receiving oral and inhaled steroids) had produced sputum showing asthmatic stigmata on a previous occasion but now had no sputum eosinophilia.

Table III shows the sputum findings in more detail, while table IV shows some of the characteristics of the subjects who produced sputum. The sputum appearance seemed to be related to nocturnal dyspnoea, family history, hay fever, and blood eosinophilia. The subjects whose sputum contained only occasional eosinophils may have been an intermediate group but their numbers were small.

\section{Discussion}

Asthma is common in children, many of whom lose their symptoms as they get older. Sometimes the disease first appears in adults (late-onset asthma). Lee and Stretton ${ }^{3}$ pointed out that bronchial asthma may occur for the first time in the elderly, in whom it may be mistakenly diagnosed as chronic bronchitis or obstructive airways disease. Furthermore, asthma that persists in adults, whatever its age of onset, tends to worsen with advancing years, and most deaths from asthma occur over the age of 55 .

Less information seems to be available about the prevalence and natural history of asthma in old people than other age groups. Late-onset asthma is usually intrinsic, ${ }^{4}$ which leads to difficulties in distinguishing it from chronic bronchitis, which is common in the elderly. The confusion is greatly increased by the MRC questionnaire definition of chronic bronchitis, which is based on a history of chronic cough and sputum. ${ }^{5}$ These symptoms also occur in asthma, so that patients with continuous asthma usually have chronic bronchitis by this definition, although it would not always be diagnosed by a clinician. This may explain conflicting statements about whether asthma precedes $^{6}$ or is preceded by ${ }^{3}$ chronic bronchitis in the elderly. Asthma may, however, be distinguished from other conditions. The lungs of patients who die from asthma show a completely different appearance from that associated with chronic bronchitis. ' Sputum of asthmatics shows characteristic patterns, the most constant being eosinophilia, provided that the patient does not simultaneously have an acute infection. ${ }^{13} 89$ The diagnosis is important because asthma responds to bronchodilators, inhaled beclomethasone, and when necessary oral steroids. Sputum eosinophilia in particular indicates an ability to respond to steroids. ${ }^{310}$

In this survey asthma was defined clinically, in terms of symptoms, reversibility of airways obstruction, and response to treatment. About $3 \%$ of the sample had reversible airways obstruction that responded to treatment and thus benefited from a diagnosis of asthma. The definition of asthma was made more difficult since some subjects were well when seen but gave a history clearly suggestive of classical asthma. Furthermore, several patients with a long history of asthma claimed that the disease had recently become much milder. This may imply that asthma may remit at any age; alternatively, it may be that older asthmatics become less active and are less inconvenienced by their disease.

The prevalance of a history of asthma was $6.5 \%$; this may be compared with a cumulative prevalence of "more certain" asthma of $5.3 \%$ previously found "in persons aged 60 years and

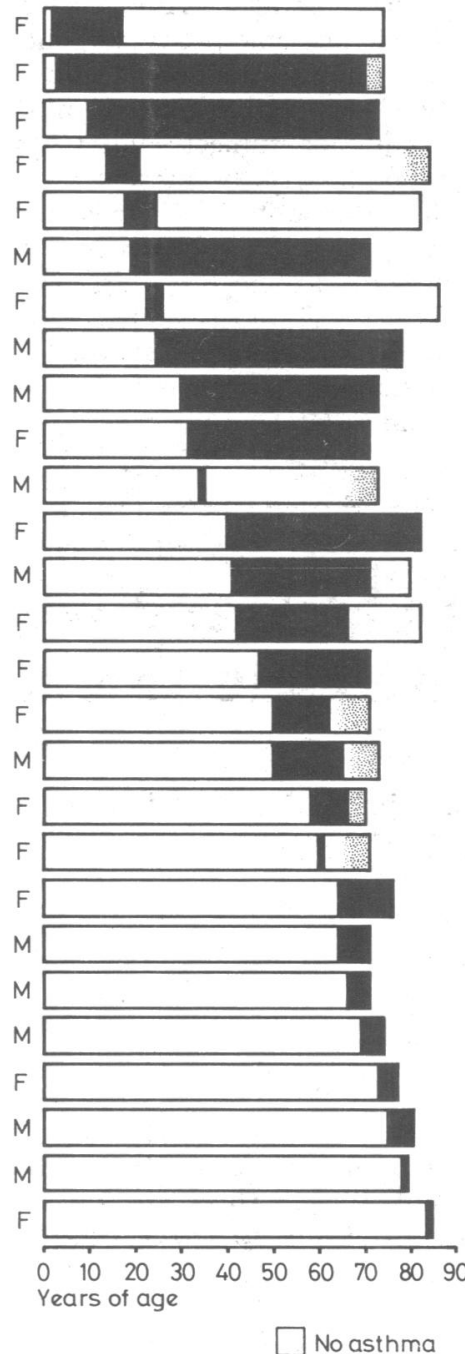

$$
\begin{aligned}
& \text { Family Hay Skin Blood Sputum } \\
& \text { history fever tests eosinophilia } \\
& \left(>0.4 \times 10^{9} / 1\right) \\
& -\quad-\quad-\quad \text { ND } \\
& +\quad+\quad+ \\
& +\quad+- \text { ND } \\
& +\quad+\quad- \\
& -\quad+\quad-\text { ND } \\
& +-\quad-\quad- \\
& -\quad-\quad-\quad \text { ND } \\
& +\quad+\quad+ \\
& \text { - }- \text { - }-1 \\
& +\quad+-\quad \text { ND } \\
& \text { - }-+ \text { - - } \\
& -\quad-\quad+\quad \text { ND } \\
& \text { - }-\quad-\quad- \\
& -\quad-\quad-\quad- \\
& +\quad-\quad+ \\
& +\quad+\text { ND }- \text { ND } \\
& +--\quad+ \\
& +\quad+\quad+ \\
& -\quad-\quad+\quad+ \\
& +\quad-\quad- \\
& +-\quad-\quad+ \\
& \text { - }-\quad-\quad- \\
& -\quad-\quad-\quad- \\
& -\quad-\quad+\quad+ \\
& +-\quad+\quad+ \\
& \text { - }- \text { - - - }
\end{aligned}
$$

Life histories of the 27 subjects with any history of asthma. Sputum eosinophilia indicates presence of focal eosinophils or other asthmatic stigmata in sputum.

$\mathrm{ND}=$ Not done.

over."11 Relatively few subjects had asthma that had started in childhood. Other surveys suggested that the prevalence of childhood asthma is about $4 \%,{ }^{12-16}$ yet only six $(1.4 \%)$ of our subjects reported asthma before the age of 20 . Some of these old people may have had childhood asthma that was not diagnosed or had since been forgotten. Furthermore, some of the original cohort might have died from early-onset asthma before reaching the age of 70. Alternatively, the prevalence of childhood asthma might have risen during their lifetime. ${ }^{17}$ Positive skin tests tended to be associated with an early onset, suggesting that the atopic status of patients with intrinsic asthma persists into old age even when the disease has remitted. Other evidence of an allergic component was the higher prevalence of a family history 
of allergy and a personal history of hay fever in the asthmatic group than the non-wheezers.

Not only was the prevalence of asthma higher in men than women but the disease also seemed to be more severe. Only four men were classed as having mild asthma or being ex-asthmatic but their lung function was noticeably impaired whereas the lung function of the 11 women in the same class resembled that of the non-wheezy women. The other wheezers included more smokers than the other groups and many of them seemed to have some degree of chronic bronchitis. Focal eosinophils and other asthmatic stigmata were associated with both a clinical diagnosis of asthma and individual characteristics of the disease. Many subjects, however, produced an asthmatic type of sputum without having any symptoms, as noted by Brown. ${ }^{10}$ Presumably such people have asthmatic tendencies without actually developing the overt disease. On the other hand some patients seemed to have clinical asthma but either they could not produce a specimen or their sputum showed no eosinophilia. If more specimens had been obtained from each subject some might have proved positive, since eosinophilia may be present intermittently. Perhaps two underlying disease processes exist that fulfil our criteria for asthma in the elderly, one causing sputum eosinophilia and the other a form of chronic bronchitis with reversible airways obstruction. This possibility is supported by the four current asthmatics who were clinically diagnosed as having chronic bronchitis plus asthma but showed no blood or sputum eosinophilia or positive skin tests.
We thank the general practitioners of Barry for their help and interest, and Dr T E Parry for the blood eosinophil counts.

Requests for reprints should be addressed to Dr M L Burr, MRC Epidemiology Unit, 4 Richmond Road, Cardiff.

\section{References}

${ }^{1}$ Sanerkin, N G, and Evans, D M D, fournal of Pathology and Bacteriology, 1965, 89, 535 .

${ }^{2}$ Burr, M L, et al, Thorax, 1975, 30, 663.

${ }^{3}$ Lee, H Y, and Stretton, T B, British Medical fournal, 1972, 4, 93.

4 Ford, R M, Medical fournal of Australia, 1969, 1, 628.

${ }^{5}$ MRC Committee on Aetiology of Chronic Bronchitis, Lancet, 1965, 1, 775.

${ }^{6}$ Manners, B T B, Journal of the Royal College of General Practitioners, 1974, 24, 167.

' Gough, J, Acta Allergologica, 1961, 16, 391.

${ }^{8}$ Epstein, R L, Annals of Internal Medicine, 1972, 77, 259

${ }^{9}$ Stretton, T B, and Lee, H Y, British Medical fournal, 1973, 1, 110

${ }^{10}$ Brown, H M, Lancet, 1958, 1, 1245.

${ }^{11}$ Broder, L, Barlow, P P, and Horton, R J M, fournal of Allergy, 1962, 33, 513.

12 Arbeiter, H E, Clinical Pediatrics, 1967, 6, 140

${ }_{13}$ Dawson, B, et al, Lancet, 1969, 1, 827.

${ }^{14}$ Williams, H, and McNicol, K N, British Medical fournal, 1969, 4, 321.

${ }^{15}$ Burr, M L, Eldridge, B A, and Borysiewicz, L K, Archives of Disease in Childhood, 1974, 49, 923.

${ }^{16}$ Hamman, R F, Halil, T, and Holland, W W, British fournal of Preventive and Social Medicine, 1975, 29, 228.

17 Smith, J M, British fournal of Diseases of the Chest, 1976, 70, 73.

(Accepted 2 March 1979)

\title{
Comparison of black and white patients attending hypertension clinics in England
}

\author{
A D MUNRO-FAURE, L J BEILIN, C J BULPITT, E C COLES, C T DOLLERY, J S S GEAR, \\ GILLIAN HARPER, B F JOHNSON
}

British Medical fournal, 1979, 1, 1044-1047

\section{Summary and conclusions}

Reports suggest that hypertension and death due to hypertensive disease are commoner among black than among white people. One hundred and thirty-five black patients attending hypertension clinics at three English

Department of the Regius Professor of Medicine, Oxford

L J BEILIN, MD, FRCP, clinical reader (now professor of medicine, University of Western Australia, Perth)

J S S GEAR, MB, DPH, fellow

Department of Clinical Pharmacology, Royal Postgraduate Medical School, London

C J BULPITT, MD, MRCP, honorary consultant physician

C T DOLLERY, MB, FRCP, professor

Department of Renal Medicine, King's College Hospital, London

B F JOHNSON, MB, MRCP, honorary clinical assistant (now professor of medicine and pharmacology, University of Massachussetts, Worcester, Massachussetts)

A D MUNRO-FAURE, BM, FRCP, honorary consultant physician (present address: Dulwich Hospital, London SE22 8PT)

Division of Computing and Statistics, Clinical Research Centre, Harrow, London

E C COLES, $M B, M T E C H$, member of scientific staff

GILLIAN HARPER, programmer hospitals were compared with age-, sex-, and clinicmatched white patients. The black women had higher blood pressures and weighed more than the white women, but there were no differences between the men.

The black patients had no increased risk from family, obstetric, or smoking history. Proteinuria and nocturia were more common in black patients while urinary infections were less common. Heart size and left ventricular voltage were greater in black patients. Haemoglobin and plasma cholesterol and triglyceride concentrations were smaller and serum globulin concentration greater in black patients.

No difference in response to treatment, attributable to race, was observed during the period of clinic attendance, which averaged 1.7 years. There was a slightly greater rate of default among black men during the first year of attendance.

\section{Introduction}

Surveys in the United States ${ }^{1-5}$ and Caribbean ${ }^{6-8}$ have consistently shown higher blood pressures in black than in white people. Death rates from hypertensive heart disease and cerebrovascular disease in the United States ${ }^{9}$ and in the United Kingdom $^{10}$ show similar differences. Since 1971 information about patients attending hypertension clinics at Hammersmith Hospital, the Radcliffe Infirmary, and King's College Hospital has been stored in a computer-based file. ${ }^{11}$ This file was examined to establish whether there were differences in clinical features at 